\title{
Development of Knapsack Sprayer Engine Operated Paddy Weeder
}

\author{
G.Ch. Chakravarthy*, P. Vidhu Kampurath and R. Ravindra Raju \\ Department of Applied Engineering, Vignan's Foundation for Science, Technology and \\ Research University - Valdamud-522213, Guntur District, Andhra Pradesh, India
}

*Corresponding author

\begin{tabular}{|c|}
\hline Keywords \\
\hline $\begin{array}{l}\text { Power Weeder, Force } \\
\text { analysis on weeder } \\
\text { blades, Paddy weeder, } \\
\text { Rotary weeder, Knapsack } \\
\text { sprayer weeder }\end{array}$ \\
\hline Article Info \\
\hline $\begin{array}{l}\text { Accepted: } \\
30 \text { March } 2018 \\
\text { Available Online: } \\
10 \text { April } 2018\end{array}$ \\
\hline
\end{tabular}

A B S T R A C T

Farming comprises of land preparation, sowing, plant protection, harvesting and post harvesting. The power source of farm machinery in every aspect is an engine, which is the costliest one in relation with the remaining parts of that machinery. If we could use the same source of power for different aspects, investment could be benefitted with multipurpose operations. Most of the farmers own some frequently required equipment like sprayer for fertigation. The engine of the common sprayer is $1 \mathrm{hp} 2$-stroke or 4-stroke with an RPM of 3000 to 9000 . If we could use this engine for weeding and harvesting of the crop, that could be an economical practice. Various types of mechanical weeders have been developed by researchers. In human operated weeders, muscular power is required and so it cannot be operated for long time. The traditional weeding is time consuming and demands high man power. To economically use the knapsack sprayer engine a single row power weeder is designed and developed in Department of Applied Engineering, VFSTR, Vadlamudi. The developed weeder is a $0.81 \mathrm{~kW}$, a 2 -stroke petrol engine, with compact and light weight, having a durable floating system. It is centrally driven with worm gear box for transmission. The working width of the developed machine is $180 \mathrm{~mm}$. It is equipped with rotating blades, having $200 \mathrm{rpm}$. Due to compactness and light weight it is easy to carry and operate. The power transmission from the engine to the blade is done by means of a flexible shaft. The shaft dimensions were designed for the adequate strength by using standard formulae for torque and power transmission. The developed machine was field tested and found working effectively.

\section{Introduction}

Weed control is one of the most difficult tasks in agriculture especially in paddy fields that accounts for a considerable share of the cost involved in agriculture production.

Weeding out unwanted plants manually, consumes 33 percent of the cost invested in cultivation, thereby reducing the profit share of farmers. A weed is a plant growing where it is not wanted, especially among crops garden plants. A weed can be thought of as any plant growing in the wrong place at the wrong time and doing more harm than good (Parish, 1990). It is a plant that competes with crops for water, nutrients and light, thus reduces crop production. Some weeds have beneficial uses but not usually when they are growing among crops. Weeds waste excessive 
proportions of farmer's time, thereby acting as a brake on development (Lavabre, 1991).

\section{Present study}

The possibility of mechanization of the weeding operation, the knapsack sprayer engine operated wetland paddy weeder is proposed to be designed. There are number of implements available in market, considering the optimum shape, size and location of cutting blades, evaluation of its performance with other weeding methods in field conditions, optimization of dimensions of machine for better performance is essential. The main objective is to design and fabrication of a knapsack sprayer engine operated wet land paddy weeder, cost effectiveness, along with minimum damages done to rice plants, easy handling, low weight and fabrication by using freely available components and easy maintenance. The relevance of mechanized weeding is relevant which is not time consuming and significantly improves weeding efficiency as well as the quality of weeding with a simple cutting blade mechanism attachment to the knapsack power sprayer engine.

Considering the above, a study has been taken up to develop a weeder with the following objectives:

\section{Objectives of the present study}

To design and develop a rotary type cutting mechanism for weeding.

To develop an effective transmission system for power transfer.

To design and develop a frame to hold gearbox and cutting mechanism.

To evaluate field efficiency comparison with hand weeding.

\section{Mechanical weed control}

Kepner et al., (1978) claimed that mechanical method of weed control is the best with little or no limitation because of its effectiveness. According to Kepner et al., (1978) Buckingham (1976), the primary objective of row crop cultivation is to enhance the use of farm machinery for eliminating weeds from the crop land. The effect of this method is to promote plant growth and better quality crops.

Biswas (1984) reported that the control of weeds is oldest far method of weed control though it received less scientific attention us compared to the other methods of weed control. The mechanical weed control methods are extensively used and shall be used in many developing countries including India because agricultural labor in these countries is cheap and easily available. Mechanical methods of weed control are simple and easily understood by farmers. The tools and implements for mechanical weed control are mostly manual and animal operated. Mechanical control of weeds involves use of weeders operated by human labor, animal drawn or tractor drawn weeders, self-propelled weeders or power weeders.

\section{Power weeders}

Power weeders are self-propelled walking type machines used for weeding specially in lowland rice.

A hand held mower was designed and fabricated at J.N.K.V.V., Jabalpur. In this model, a small petrol engine was mounted on a portable frame. The petrol engine was similar to the ones, which were used in sprayers and dusters. The knife blade of a 45 $\mathrm{cm}$ cutter bar was operated Anonymous (1979).A rotary mower was also designed for cutting grasses, bushes and other weeds with stem. The engine of $35 \mathrm{cc}$ capable of 
developing $1.7 \mathrm{hp}$. at $6000 \mathrm{rpm}$ was used and a horizontal circular rotary blade was used for cutting.

Hegazy et al., (2014) developed a power weeder for maize crop with modified vertical blades which were mounted on a circular rotating element on its horizontal side; the motion was transferred to blades units by amended transmission system. The effect of weeder forward speeds, depth of operation, number of blades and soil moisture content on fuel consumption, plant damage, weeding index, effective field capacity, field efficiency, energy required per unit area and total cost were studied. Three levels of soil moisture content (7.73, 12.28 and $16.18 \%)$, two blades arrangements (two and four vertical blades for each unit), three weeder forward speeds (1.8, 2.1 and $2.4 \mathrm{~km} / \mathrm{h}$ ) and two depths of operation (from 0 to 20 and from 20 to $40 \mathrm{~mm}$ ) was chosen. The results showed that, the minimum value of fuel consumption was $0.546 \mathrm{l} / \mathrm{h}$ and recorded by using two blades with $1.8 \mathrm{~km} / \mathrm{h}$ weeder forward speed at depth of operation ranged from 0-20and soil moisture content $16.18 \%$. The highest field efficiency was $89.88 \%$ by using two blades with $1.8 \mathrm{~km} / \mathrm{h}$ weeder forward speed at depth of operation ranged from 0 to $20 \mathrm{~mm}$ and soil moisture content $16.18 \%$. The minimum value of effective field capacity was $0.198 \mathrm{fed} / \mathrm{h}$ by using four blades, weeder forward speed 1.8 $\mathrm{km} / \mathrm{h}$, soil moisture content $7.73 \%$ and under depth of operation ranged from $20-40 \mathrm{~mm}$. The lower value of total cost was 55.09 L.E /fed and was obtained by using two blades with $2.4 \mathrm{~km} / \mathrm{h}$ weeder forward speed at depth of operation ranged from $0-20 \mathrm{~mm}$ and soil moisture content $16.18 \%$.

\section{Experimental site}

The study was conducted in VFSTR, Vadlamudi, Guntur District, Andhra Pradesh, situated at $16^{\circ} 14^{\prime} 0.29^{\prime \prime} \mathrm{N}$ latitude and
80³3'2.84"E longitude. The operational field meant for the study was selected from the demonstration / research field of the university.

\section{Power requirement}

\section{Theoretical considerations}

Soil resistance has a considerable effect upon the power requirement of weeder. Also, depth of cut, width of cut and speed of operation influences power requirement of weeder. For calculating power requirement of the weeder, maximum soil resistance was taken as 0.7 $\mathrm{kgf} / \mathrm{cm}^{2}$. The speed of operation of the weeder was considered as $0.5 \mathrm{~m} / \mathrm{s}$. Total width of coverage of cutting blades was $18 \mathrm{~cm}$. The depth of operation was considered as $8 \mathrm{~cm}$, transmission efficiency is $50 \%$.

The power required to cut the soil ' $\mathrm{P}_{\mathrm{d}}$ ' is,

$\mathrm{P}_{\mathrm{d}}=\frac{S R * d * W * V}{75}$

Where,

$\mathrm{P}_{\mathrm{d}}$ - Power required to cut the soil

$\mathrm{SR}$ - Soil resistance, N/mm ${ }^{2}$

$\mathrm{d}$ - Depth of cut, $\mathrm{cm}$

w - Effective width of cut, $\mathrm{cm}$

$\mathrm{v}$ - Speed of operation, $\mathrm{ms}^{-1}$

Hence, power requirement is estimated as,

$$
\begin{aligned}
& =\frac{0.069 * 8 * 18 * 0.5}{75} \\
& P_{d}=0.0065 \mathrm{hp}=0.0048 \mathrm{~kW}
\end{aligned}
$$

\section{Total power required}

The total power required ' $\mathrm{P}_{\mathrm{t}}$ ' is,

$$
\mathrm{P}_{\mathrm{t}}=\frac{\text { Pd }}{\mathrm{n}}(3.2)
$$


Where,

$\mathrm{P}_{\mathrm{t}}$ - Total power required

$\mathrm{P}_{\mathrm{d}}$ - Power required to cut the soil

$\eta$ - Transmission efficiency.

$\mathrm{P}_{\mathrm{t}}=0.0096 \mathrm{~kW}$

Thus, any knapsack power sprayer can be used, usually knapsack power sprayers ranges from $0.5 \mathrm{hp}$ to $1.5 \mathrm{hp}$. (i.e., 0.4 to $1.1 \mathrm{~kW}$ ).

\section{Gear selection}

For transferring the rotary motion from sprayer engine to the reduction gearbox the flexible shaft is selected. The RPM of the engine ranges from 3000 to 9000 (Fig. 1).

The rotational power is to be reduced to 100 to 300 and the best suited with minimum sound and vibration is a Worm Gear, which are ready to purchase in market with different ratios and selected was 30:1 as we have the range of 3000 to 9000 RPM.

\section{Design of shaft}

\section{Torque transmitted by the shaft}

The torque ' $\mathrm{T}$ ' transmitted through the shaft is worked out using the following equation (Khurmi, 2012).

$\mathrm{T}=\frac{\mathrm{P} * 60 * 1000}{2 * \pi * \mathrm{~N}}$

Where,

$\mathrm{T}$ - Torque transmitted by the shaft, $\mathrm{Nm}$

$\mathrm{P}$ - Power, kW

$\mathrm{N}$ - Revolutions of the prime mover per minute

Considering engine minimum speed as 3000 rpm and engine power $0.81 \mathrm{~kW}$ we get torque as,
$\mathrm{T}=\frac{0.81 * 60 * 1000}{2 * \pi * 3000}$

$\mathrm{T}=2.577 \mathrm{Nm}$.

Thus the maximum torque of $2.58 \mathrm{Nm}$ was generated at engine.

\section{Diameter of the flexible shaft}

The maximum tangential force which can be endured by the rotor should be considered (Fig. 2).

The maximum tangential force occurs at the minimum tangential speed is calculated by the following (Bernacki et al., 1972)

$\mathrm{K}_{\mathrm{S}}=\frac{\boldsymbol{C}_{s} * 75 * N_{G} * \mathrm{n}_{\mathrm{c}} * \mathrm{n}_{z}}{\mathrm{U}}(3.4)$

Where,

$\mathrm{K}_{\mathrm{S}}$ - Maximum tangential force, $\mathrm{kg}$,

Cs - Reliability factor (1.5 for non-rocky soils and 2 for rocky soils),

$\mathrm{N}_{\mathrm{C}}$ - Power of engine, hp,

$\eta_{c}$ - Traction efficiency for the forward rotation of rotor shaft as 0.9 ,

$\eta_{\mathrm{z}}$ - Coefficient of reservation of engine power (0.7-0.8),

$\mathrm{u}$ - Minimum tangential speed of the rotor

Tangential peripheral speed, $\mathrm{u}$, can be calculated using the following equation,

$u=\frac{2 * \pi * N * R}{6000}(3.5)$

Where,

$\mathrm{N}$ - Revolution of rotor, rpm, and

$\mathrm{R}$ - Radius of rotor, $\mathrm{cm}$. 


$$
\begin{aligned}
& \mathrm{u}=\frac{2 * \pi * 3000 * 0.75}{6000} \\
& \mathrm{u}=2.357 \mathrm{~m} / \mathrm{s}
\end{aligned}
$$

By substituting the " $u$ " value in the equation (3.4) we get,

$$
\begin{aligned}
& \mathrm{K}_{\mathrm{S}}=\frac{1.5 * 75 * 1.08 * 0.9 * 0.8}{2.357} \\
& \mathrm{~K}_{\mathrm{S}}=37.327 \mathrm{~kg} .
\end{aligned}
$$

After substituting values for revolution of rotor shaft $(3000 \mathrm{rpm})$, tangential peripheral speed was obtained as $2.357 \mathrm{~m} / \mathrm{s}$. Using the tangential peripheral speed and other parameters in equation, the maximum tangential force was determined to be 37.327 $\mathrm{kg}$.

The maximum moment on the rotor shaft $\left(\mathrm{M}_{\mathrm{s}}\right)$ is calculated through the following:

$\mathrm{M}_{\mathrm{S}}=\mathrm{K}_{\mathrm{S}} * \mathrm{R}(3.6)$

$\mathrm{M}_{\mathrm{S}}=37.327 * 0.75$

$\mathrm{M}_{\mathrm{S}}=27.995 \mathrm{~kg}-\mathrm{cm}$

In the above equation, $\mathrm{R}$ is the rotor radius (cm).

The yield stress of rotor made from Stainless steel (AISI 304) was $504 \mathrm{MPa}$. The allowable stress on the rotor ( $\tau$ all) was calculated by the following equation (Mott, 1985):

Tall $=\frac{0.577 * \mathbf{k} * \sigma_{y}}{\mathbf{f}}$

Where,

$\tau_{\text {all }}$ - Allowable stress on rotor shaft, kg.cm ${ }^{-2}$,

$\mathrm{k}$ - Coefficient of stress concentration (0.75),

$\sigma_{\mathrm{y}}-$ Yield stress, $504 \mathrm{MPa}$.

f - Coefficient of safety (1.5), [yield stress / working stress] and

$$
\begin{aligned}
\text { Tall } & =\frac{0.577 * 0.75 * 504}{1.5} \\
\text { Tall } & =145.404 \mathrm{MPa} .=1482.714 \mathrm{~kg} / \mathrm{cm}^{2}
\end{aligned}
$$

By substituting above values in the following equation, rotor shaft diameter was calculated,

$$
\begin{aligned}
\mathrm{D} & =\sqrt[3]{\frac{16 * M_{s}}{\tau_{a l l} * \pi}}(3.8) \\
\mathrm{D} & =\sqrt[\sqrt[s]{16 * 27.995}]{1482.708 * \pi} \\
\mathrm{D} & =0.458 \mathrm{~cm}
\end{aligned}
$$

In order take into account fluctuating load during the operation, diameter of the shaft must be selected higher than the calculated value. Hence we selected $1.5 \mathrm{~cm}$ shaft for the construction.

\section{Design of cutting blades}

Assumption was made as follows;

Number of blades in one working set $=4$

Length of blade $=22.5 \mathrm{~cm}$

Width of cutting blade $=15 \mathrm{~cm}$.

To calculate the design strength of blade, revolution per minute of rotor shaft ' $\mathrm{N}$ ' $=100$ r.p.m. radius of engine output rotor $(\mathrm{R})=1.5$ $\mathrm{cm}$. Therefore, speed of engine output $(\mathrm{u})$ is determined in eq. (3.5), as $2.357 \mathrm{~ms}^{-1}$.

For cutter blade design, number of blade, cutting width and thickness were important parameters. During cutting, blades would be subjected to shearing as well as bending stresses. Total working width of the weeder was $180 \mathrm{~mm}$. Total of 4 blades were provided with cutting width of $150 \mathrm{~mm}$.

The soil forces acting on the blade $\left(\mathrm{K}_{\mathrm{e}}\right)$ was calculated by the following equation,

$\mathrm{K}_{\mathrm{e}}=\frac{\boldsymbol{K}_{s} * C_{p}}{\mathrm{i} * Z_{e} * n_{e}}(3.9)$ 
Where,

$\mathrm{K}_{\mathrm{e}}$ - The soil forces acting on the blade

$\mathrm{K}_{\mathrm{s}}$ - Maximum tangential force, $\mathrm{kg}$,

$\mathrm{C}_{\mathrm{p}}$ - Coefficient of tangential force as 0.8 ,

I - Number of flanges, 1,

$Z_{e}$ - Number of blades on each side of the flanges is 4 and

$\mathrm{n}_{\mathrm{e}}$ - Number of blades which act jointly on the soil, $1 / 2$.

$\mathrm{K}_{\mathrm{e}}=\frac{37.327 * 0.8}{1 * 4 *(1 / 2)}=14.931 \mathrm{~kg}$.

By solving, the soil force acting on the blade ' $\mathrm{K}_{\mathrm{e}}$ ' was determined as $14.931 \mathrm{~kg}$.

The dimensions of the blades are given in Figure 3.

\section{Description of machine components}

Based on design values of different components, a knapsack sprayer engine operated weeder was fabricated. A power source of $0.81 \mathrm{~kW}$ with a 6000 rated rpm, twostroke petrol engine was selected, which was capable of providing the required power.

The technical specifications of the engine are shown in Table 1.

\section{Power unit}

The power required for wetland rice interculture is about $1 / 2$ to $1 \mathrm{hp}$ per row (Olaye et al., 2003). The engine selected was a knapsack sprayer engine, i.e. $0.81 \mathrm{~kW}$ therefore can cope with the draft requirement for one row. Hence, a single cylinder, 2-stroke petrol engine, recoil start of $25.4 \mathrm{cc}$ with air cooled engine was used as a prime mover for the rice power weeder (Fig. 4).

\section{Transmission}

A flexible shaft is selected and connected at one end with the engine clutch assembly and other end is with a 30:1 reduction gear box with a little alterations. The output of the gear box is transmitted to a $25 \mathrm{~mm}$ diameter and $150 \mathrm{~mm}$ long shaft. The shaft is fitted in the gear box with a key and washer with bolt. The other end of the shaft is welded with a $5 \mathrm{~mm}$ round flange, where the blades get fixed.

\section{Design of frame}

A frame with $450 \times 180 \times 150 \mathrm{~mm}$ was designed as the cutting bottom must fit in between the paddy rows. Another Five ' $L$ ' shaped MS rods were used to hold the engine along with fuel tank at a fixed position (Fig. $5)$.

\section{Handle}

Handle is made of $20 \mathrm{~mm}$ MS pipe with the length $1000 \mathrm{~mm}$. The overall length of the frame is $850 \mathrm{~mm}$. The handle is attached on the bottom of the engine at the rear of the machine with help of 2 clamps with nuts and bolts of having diameter of $10 \mathrm{~mm}$. With help of handle, the machine can be steered. A throttle lever and power cutoff switch is provided on the handle to control the engine speed.

\section{Theoretical field capacity}

Theoretical field capacity of the machine is the rate of field coverage that would be obtained if the machine were performing its function $100 \%$ of the time at the rated forward speed and always covered $100 \%$ of its rated width. It is expressed as hectare per hour and determined as follows (Kepner et al., 1978). 
$\mathrm{TFC}=\frac{\frac{W * s}{10}}{10.17)}$

Where,

TFC $=$ Theoretical field capacity, ha/h

$\mathrm{w}=$ Width of cut, $\mathrm{m}$

$\mathrm{s}=$ Speed of operation, $\mathrm{Km} / \mathrm{h}$

$\mathrm{TFC}=(0.18 * 1.8) / 10$

$\mathrm{TFC}=0.03$ ha. $/ \mathrm{hr}$.

Force analysis of the blade using software

ANSYS 14.0 is used to analyze the forces on the blade. We concentrated on Total Deformation, Stress and Strain and the inputs are Density, Young's Modules and Poison's Ratio.

\section{Results and Discussion}

\section{Fabrication and assembling of the machine}

The design was altered with,

The place of Engine was altered from the backpack to the rear side of the cutting bottom.

Reduced the handle size.

Collar of the shaft was altered from $10 \mathrm{~mm}$ size to $15 \mathrm{~mm}$ shaft to fit the gear box. Frame was altered to hold the engine.

A bearing was placed on the flexible shaft instead of casing, to avoid direct contact between shaft and frame.

Two more ' $L$ ' shaped clamps were attached to the previously constructed frame to hold the frame.

\section{Weeding efficiency}

Weeding efficiency was calculated for the test field with 3 replicationsR1, R2 R3as depicted in Table 1.

\section{Plant damage}

The plant damaged for different replications are depicted in Table 2.

\section{Fuel consumption}

Fuel consumption of the power weeder was calculated by topping method. It was observed that the fuel consumption varied between 0.55 to $0.7 \mathrm{l} / \mathrm{h}$.

\section{Operational parameters}

\section{Moisture content of soil}

Eight soil samples were taken randomly from four replications on an interval of 15 DAS, 25 DAS and at 35 DAS from the soil surface. The average moisture content at 15 DAS is $26.26 \%$, at 25 DAS is $25.27 \%$ and at 35 DAS is found as $21.42 \%$ on dry basis. Details observed data are represented in Table 3.

\section{Force analysis of the blade using ANSYS 14.0}

Force analysis was done using ANSYS 14.0 for the blade material Low Carbon Steel (Mild Steel) along with two more materials, which are usually used in blade manufacturing i.e. stainless steel and boron steel.

\section{Inputs of material properties}

The details of material properties for Low Carbon Steel (AISI Px), Stainless Steel (AISI 304) and Boron Steel (AISI xxBxx) are represented in Table 4. 
Table.1 Technical specifications of the machine

\begin{tabular}{|c|c|c|}
\hline S.No. & Specification & Value \\
\hline 1 & Number of cylinder & 1 \\
\hline 2 & Engine maximum power at 6000 & $0.81 \mathrm{~kW}$ \\
\hline 3 & $\mathrm{rpm}$ & 3000 to 9000 \\
\hline 4 & Weeding width & $180 \mathrm{~mm}$ \\
\hline 5 & No. of Blades & 4 \\
\hline 6 & Rotor speed & 200 at rated rpm \\
\hline 7 & Weeding depth & 3 to $8 \mathrm{~cm}$ \\
\hline 8 & Power transmission & $\begin{array}{l}\text { Lightweight } \\
\text { aluminium worm } \\
\text { gear box }\end{array}$ \\
\hline 9 & Fuel tank capacity & $1.0 \mathrm{Lt}$. \\
\hline 10 & Fuel & $\begin{array}{l}\text { Petrol with } 2 \mathrm{~T} \text { oil } \\
\text { (1 Lt. petrol with } 40 \\
\text { ml } 2 \mathrm{~T} \text { oil) }\end{array}$ \\
\hline 11 & Material of blade & Mild Steel \\
\hline 12 & Total weight & $18.5 \mathrm{~kg}$. \\
\hline
\end{tabular}

Table.2 Effect of the blades of power weeder at different replications on weeding efficiency (\%)

\begin{tabular}{|c|c|}
\hline Replication & Weeding efficiency (\%) \\
\hline R1 & 80.97 \\
\hline R2 & 81.42 \\
\hline R3 & 82.17 \\
\hline
\end{tabular}

Table.3 Effect of the cutting blades of power weeder at different replications on plant damage $(\%)$

\begin{tabular}{|c|c|}
\hline Replication & Plant Damage (\%) \\
\hline R1 & 2.03 \\
\hline R2 & 1.85 \\
\hline R3 & 1.3 \\
\hline
\end{tabular}

Table.4 Material properties for the selected materials

\begin{tabular}{|c|c|c|c|}
\hline Material & Density (kg/cu.m) & Young's Modules (P) & Poison's Ratio \\
\hline Low Carbon Steel & 7850 & $2.1 \mathrm{E}+11$ & 0.3 \\
\hline AISI P6 & 8000 & $1.93 \mathrm{E}+11$ & 0.3 \\
\hline Stainless Steel & 8030 & $2.1 \mathrm{E}+11$ & 0.3 \\
\hline AISI 304 & & & \\
\hline AISI 94B30 & &
\end{tabular}


Table.5 Analysis outputs from ANSYS 14.0

\begin{tabular}{|c|c|c|c|c|}
\hline & & Deformation & Stress & Strain \\
\hline \multirow{2}{*}{ Mild Steel } & Min & 0 & 2.3301 & $1.1096 \mathrm{E}-11$ \\
\hline & Max & $8.1944 \mathrm{E}-05$ & 51788 & $2.5348 \mathrm{E}-\mathrm{O} 7$ \\
\hline \multirow{2}{*}{ Stainless Steel } & Min & 0 & 2.3301 & $1.2073 \mathrm{E}-11$ \\
\hline & Max & $8.9162 \mathrm{E}-05$ & 51788 & $2.7581 \mathrm{E}-07$ \\
\hline \multirow{2}{*}{ Boron Steel } & Min & 0 & 2.3301 & $1.1096 E-11$ \\
\hline & Max & 8.1944E-O5 & 51788 & $2.5348 \mathrm{E}-07$ \\
\hline
\end{tabular}

Fig.1 Reduction Gearbox 30:1

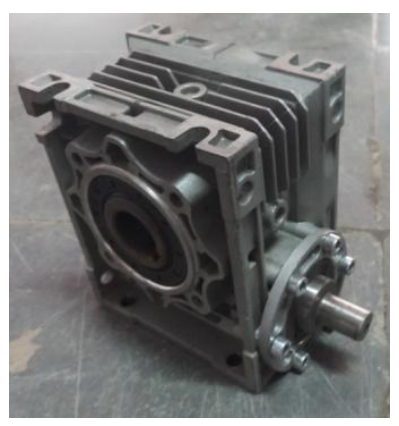

Fig.2 Flexible shaft of $15 \mathrm{~mm}$

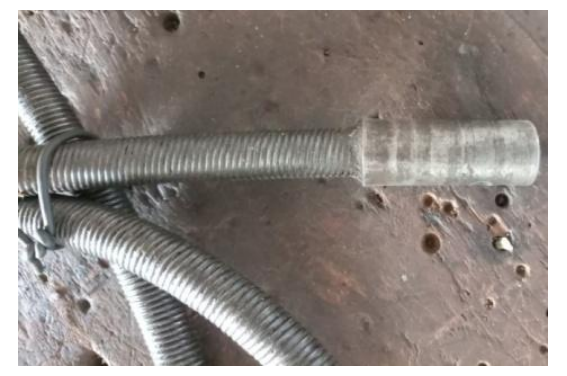

Fig.3 The dimensions of the blades

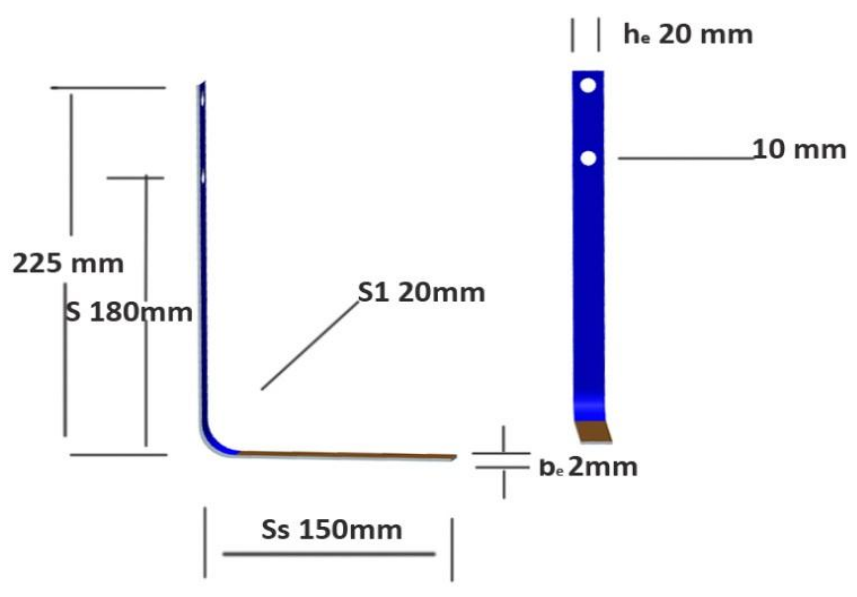


Fig.4 Engine assembly

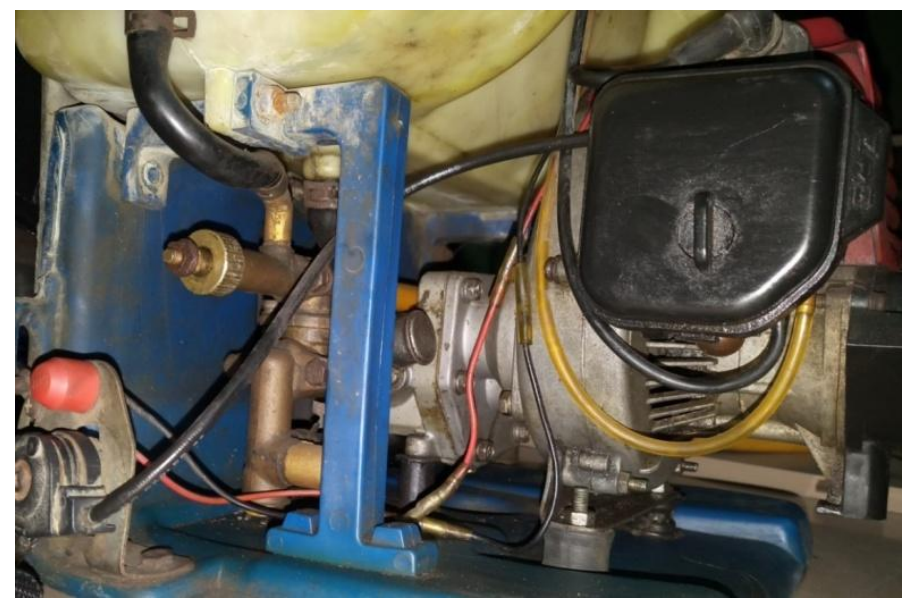

Fig.5 Frame construction

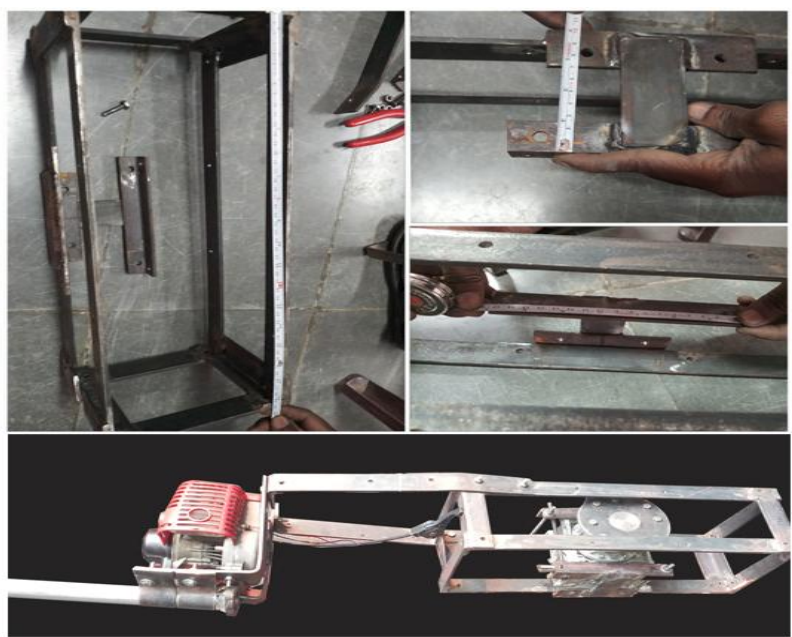

Fig.6 Assembly of engine

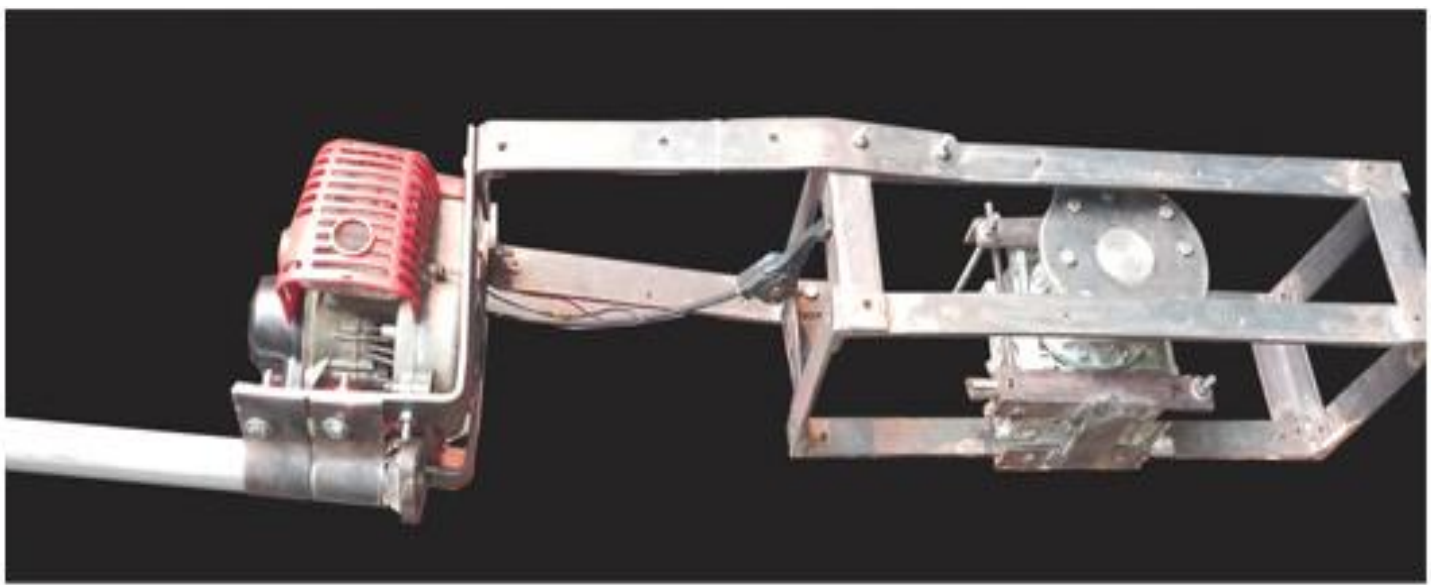




\section{Total Deformation}

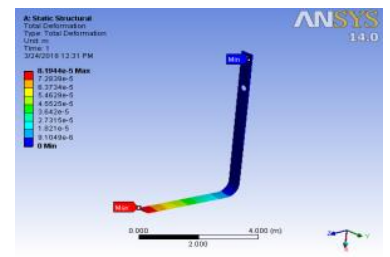

Low carbon Steel

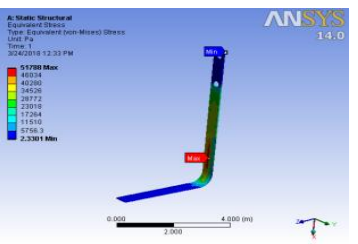

Low carbon Steel

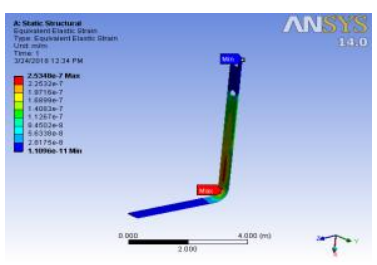

Low carbon Steel

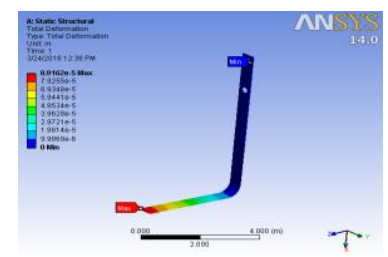

Stainless Steel

Equivalent Stress

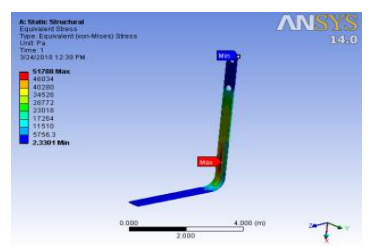

Stainless Steel

Equivalent Elastic Strain

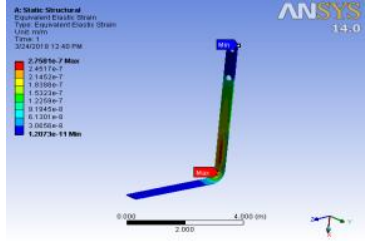

Stainless Steel

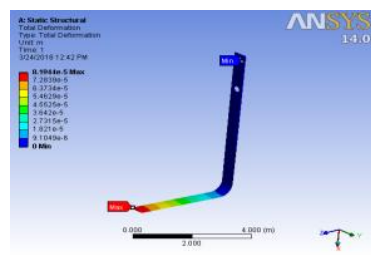

Boron Steel

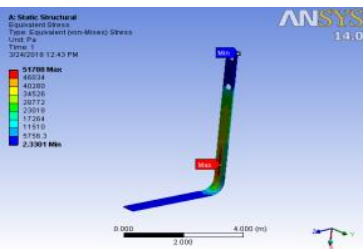

Boron Steel

\section{Outputs we find}

The outputs we find with the software ANSYS 14.0 for Total Deformation, Stress and Strain are given in Table 5.

The following conclusions could be drawn.

The working width of the developed machine was $180 \mathrm{~mm}$.

The cutting blades move with forward speed of $2.48 \mathrm{~km} / \mathrm{h}$ and depth of operation ranged from $3-4.5 \mathrm{~cm}$, with fuel consumption of 0.55 $\mathrm{l} / \mathrm{h}$, and minimum value of plant damage taking low power from engine to operate the weeder.
The minimum value of theoretical field capacity was $0.03 \mathrm{ha} / \mathrm{hr}$ obtained at a forward speed $2.48 \mathrm{~km} / \mathrm{h}$, and at a maximum depth of operation was found as $3.5 \mathrm{~cm}$. and fuel consumption was observed as $0.7 \mathrm{l} / \mathrm{h}$.

The operating cost of the machine was Rs.980/ha with compared to Rs. 2300/ha for manual weeding

The saving in cost of weeding was $60 \%$ and saving in time was $65 \%$ when compared to manual weeding.

The performance of rice weeder was found excellent on wet condition. 


\section{Suggestions for future work}

Weeder can be designed to perform more than one operation using the same prime mover i.e. both for wet and dry land condition.

Fabrication was found heavier than expectation, a fibre body might suit for the weeder to be light and easy to handle.

Further research is required to make the approach-1 successful, which can facilitates number of other farm applications for small farmers.

\section{References}

Agarwal, J.P. and Singh, O.P. 1968. All about weeds. Atual Publishing House, Aligarh.

Alizadeh, M.R. 2011. Field performance of mechanical weeder in the rice field. Scientific Research and Essays, Vol. 69 (25):5427-5434.

Ambujam. 1984. Evaluation of power weeder performance. Agricultural Mechanization in Asia, Africa and Latin America, 24 (4): 16

Anonymous. 1983. Testing evaluation and modification of weeder. Technical series No. II. RNAM of ESCAP, Philippines.

Anonymous. 1985 RNAM test codes and procedure for farm machinery, Technical series No. 12, Economic and Social Commission for Asia and the Pacific, Regional Network for Agricultural Mechanization, Bangkok, Thailand.

Anonymous. 1997. CIAE self - propelled weeder. Annual report. Central Institute of Agricultural Engineering, Bhopal.

Anonymous. 2014. Annual report - 2013-14. Department of Agriculture and Cooperation, Ministry of Agriculture, Govt. of India, New Delhi.
Anyawu, A.C., Anyawu, B.O., Anyawu, A.A. 1976. Agriculture for school certificate. Africana Education Publication (Nig.) in association with FEP Int. Ltd.

Bajwa, A.A. 2014. Sustainable weed management in conservation agriculture. Crop protection, 65:105113.

Balachand, C.H. 2006. Design, development and evaluation of animal drawn weeder suitable for non-descript bullock of C.G. region. M.Tech. Thesis, Indira Gandhi Krishi Vishwa Vidyalaya, Raipur.

Behera, B.K., Behera. D., Swain. S., Sahu, R.K. 1996. Performance evaluation of manual weeders for rice crop in Orissa. Agricultural Mechanization in Asia, Africa and Latin America, 27(3):82022.

Bernacki, H., Haman, J. and Kanafojski, C.Z. 1972. Agricultural machines, theory and construction. US Department of Agriculture and National Science Foundation, Washington D.C.

Bhardwaj, K.C., Ganesan, S., Pandey, M.M., Singh, G. 2004. Equipment for weeding and inter-cultivation. Directory of Agricultural Machinery and Manufacturers. NATP. Prototype Manufacturing of Agricultural Implements. Central Institute of Agricultural Engineering, Bhopal.14656.

Bin Ahmad, M.T. 2012. Development of an automated mechanical intra row weeder for vegetable crops. Thesis, Digital Repository, Graduate College, Iowa State University, USA.32-38.

Biswas, H.S. 1980. Weeding tools and implements of India. Technical bulletin No.CIAE/78/3, Central Institute of Agricultural Engineering, Bhopal.

Biswas, H.S. 1984. Weed control techniques. Technical bulletin No, CIAE/84/46, 
Central Institute of Agricultural Engineering, Bhopal.

Biswas, H.S., Ingale, G.S. and Ojha, T.P. 1991. Development of animal drawn weeder in India. Agricultural Mechanisation in Asia, Africa and Latin America, 30 (40):57-62.

Bohrnsen, A. and Thomas, J.M. 1994. Several year results about mechanic weeding in cereals, Maitrisedes adventices par voiephemique. Communications data quatrieme conference intermediate IF.O.A. M.Dijon, France 5-9 July 1993 - 94 (2):95-101.

Bridger, R. S.1995. Introduction to Ergonomics. 3rd Edn., McGraw-HIll, Inc, New York.

Buckingham, F. 1976. Fundamentals of machine operation. John Deere Service Publication, Moline, Iowa, USA.

Charudattan, R. and Dinoor, A. 2000. Biological control of weeds using plant pathogens: accomplishment and limitations. Crop Protection, 19:691695.

Chauhan, B. S., Abeysekera, A.S.K., Wickramarathe, M.S., Kulatunga, S.D. and Wickrama, U.B. 2014. Effect of rice establishment methods on weedy rice (Orizya sativa L.) infestation and grain yield of cultivated rice $(\mathrm{O}$. sativa L.) in Sri Lanka. Crop Protection, 55:42-49.

Cloutier, D.C.R.Y.V.D., Weide, A., Peruzzi and Leblanc, M. L. 2007. Mechanical weed management in non-chemical weed management, principles, concepts and technology. Upadhyaya M.K and R.E Blackshaw, Edition 111-134.

Corlett, E.N. and Bishop, R.P. 1976. A technique for assessing postural discomfort. Ergonomics, 19(2), 175182.

Dakogol, F.A., Kwaya, P.V., and Yusuf, R.E. 2007. Development and performance evaluation of a garden flail mower. In Proceedings of the 8thInternational Conference and 29th Annual General meeting Yola, 5-9 Nov. 2007. Nigerian Institution of Agricultural Engineers. 73-76.

Datta, S.K., Aragon, K.L. and Mlabugoe, J.A. 1974. Varietal difference in cultural practices for upland rice. Seminar Proceeding In. Rice breeding and varietal environment. West Africa Rice Development Association, Manoroviabilaria: 35-73.

Dryden, R.D. and Krishnamurthy.1977. Year round tillage. Indian Journal of Weed Science, Vol. 9:14-18.

Duff, B. and Orcino, N. 1971. Economic research in the department of agricultural engineering. IRRI Seminar. Los Banos, Philippines: 9

Fagade, S.O. 1980.Performance of some herbicides in the control of upland rice weed in Nigeria. WARDA Technical News Letter, 2(2):9-10.

Ghosh, D.C. and Singh, R. S. 1985. Relative effectiveness of chemical and cultural methods in controlling weeds in upland rice. Annual Conference of Indian Society of Weed Science April 4-5.

\section{How to cite this article:}

Chakravarthy, G.Ch., P. Vidhu Kampurath and Ravindra Raju, R. 2018. Development of Knapsack Sprayer Engine Operated Paddy Weeder. Int.J.Curr.Microbiol.App.Sci. 7(04): 36403652. doi: https://doi.org/10.20546/ijcmas.2018.704.410 